\title{
Culture of marine algae using a re-circulating sea water system
}

\author{
W. E. Jones and E. S. Dent \\ University College of North Wales, Marine Science Laboratories; \\ Menai Bridge, Anglesey, $U . K$.
}

KURZFASSUNG: Kultur von Meeresalgen mit Hilfe eines re-zirkulierenden Seewassersystems. Ein re-zirkulierendes Seewassersystem, das der Kultivierung von Algen unter weitgehend natürlichen Umweltbedingungen dient, wird beschrieben. Vor- und Nachteile dieses Systems werden dargelegt. Als ungünstig erwiesen sich die jahreszeitlich bedingten Veränderungen der Wassertemperatur, die Anwesenheit verschiedener mariner Begleitorganismen sowie die Ablagerungen von Sediment. Das größte Hindernis für die Erhaltung weitgehend reiner Kulturen war das Vorhandensein von Diatomeen und anderer einzelliger Algen, deren Entfernung große Schwierigkeiten bereitete. Die Zahl und Artenzusammensetzung der Algen, welche die Kulturen in unerwünschter Weise bevölkerten, änderten sich in Abhängigkeit von der Jahreszeit und der Lichtintensität. Das beschriebene Kultursystem wurde benutzt, um die Wirkung des Lichts auf das Wachstum junger Rotalgenthalli zu untersuchen. Für kurzfristige Experimente erwies sich die hier erprobte Kulturmethode als sehr befriedigend. Die Bedeutung dieser Methode für die experimentelle Taxonomie sowie generell für die Hälterung von Algen im Labor wird herausgestellt.

\section{INTRODUCTION}

The culture of marine algae in the laboratory for the purpose of physiological experiments has, in the main, been carried out using artificial culture media. This has an obvious advantage, providing uni-algal cultures of the species under observation are required. However, it also provides an environment for algal growth which is inevitably artificial, and leads to the speculation that the species studied may react rather differently under more natural conditions, as for example, if untreated sea water is used.

The present paper is concerned with a description of a system used for work on the growth of the larger Rhodophyceae and to a lesser extent, the Phaeophyceae. While it is possible to grow filamentous red algae successfully in small vessels of sea water or culture medium, the larger more solid red algae seldom grow satisfactorily under these conditions. However, good growth, and the maintenance of normal morphology, can be obtained in systems where the plants are grown in a constant flow of sea water. Experiments concerned with algal growth have been carried out using natural sea water (Jones 1957, 1959, Neushul \& Haxo 1963, Neushul et al. 
1967, Neushul \& Dahl 1967). In all cases continuous flow systems were used in which the water was discarded after use.

Various species of the larger algae have been grown in Menai Bridge for the past fourteen years. Our basic method was to grow the plants in shallow dishes into which sea water was passed from the main laboratory system. This system pumps water from the Menai Straits into sedimentation tanks, and thence, after as long a period as possible for settlement, to header tanks in the roof $(12 \mathrm{~m}$ above the sedimentation tanks). From there the water is piped to various laboratories by gravity. It is discarded to waste after passing through the culture dish.

The water of the Menai Straits contains considerable quantities of sediment, particularly at the spring tides and in stormy weather, and at certain times of the year contains numerous larval stages of sedentary marine animals. This combination leads to difficulties and, as demands in the system have increased, the time which can be allowed for sedimentation has become very short. This can be very serious in some experiments when, owing to the illumination system, heating will occur in the culture dish if the water should cease to flow. Nevertheless, the system allowed us to grow a large number of species before difficulties became too great.

Three years ago, we were able to design a new system when the algal division of the Marine Science Laboratories moved to a new building too far from the old laboratory to permit connection to the existing system. In order to try to retain the advantage of continuous flow culture (but at the same time to reduce the difficulties resulting from sediment, animal larvae and algal spores) we decided to build a re-circulating system. We realised that there might be difficulties resulting from the accumulation of waste products and temperature rise, but felt that these could be minimised and would be of less importance than having an uncertain water supply.

\section{DESCRIPTION OF THE RE-CIRCULATING SEA WATER SYSTEM IN USE AT MENAI BRIDGE}

The closed circulation sea water system is shown diagramatically in Figure 1. From the main storage tanks, $\mathrm{T}_{1}$ and $\mathrm{T}_{2}$, water is pumped to a header tank, $\mathrm{H}$. The pump is of non-toxic material, and is controlled by a float system in the header tank. From tank $\mathrm{H}$ the water flows by gravity to the experimental benches in the laboratory. Two such benches are shown in Figure 1; the water supply to them is controlled by valves $V_{1}$ and $V_{2}$. Valve $V_{3}$ controls the flow to a third bench, located above bench $\mathrm{B}_{2}$ but not shown in the diagram. The outflow pipe from this upper bench joins that of bench $\mathrm{B}_{2}$. The storage tanks, pump and header tank are located outside the laboratory building.

Non-toxic materials are used throughout the system. The storage tanks are each of 4,400 1 capacity and are constructed of welded, white polypropylene sheet supported by steel framing. Each tank is provided with a wooden cover. The header tank is a standard domestic black polypropylene tank, of 4501 capacity, enclosed in a timber housing. All piping is standard domestic black polythene. Nylon or poly- 
thene taps are used for controlling the supply to the experimental benches. The latter are of two types; the lower benches are constructed of wood, covered with sheet lead; the upper bench of white polypropylene sheet, supported on a framework of timber and aluminium. Each lower bench has a drainage channel fitted with an outflow pipe, by means of which water is returned to the storage tanks for re-circulation. There

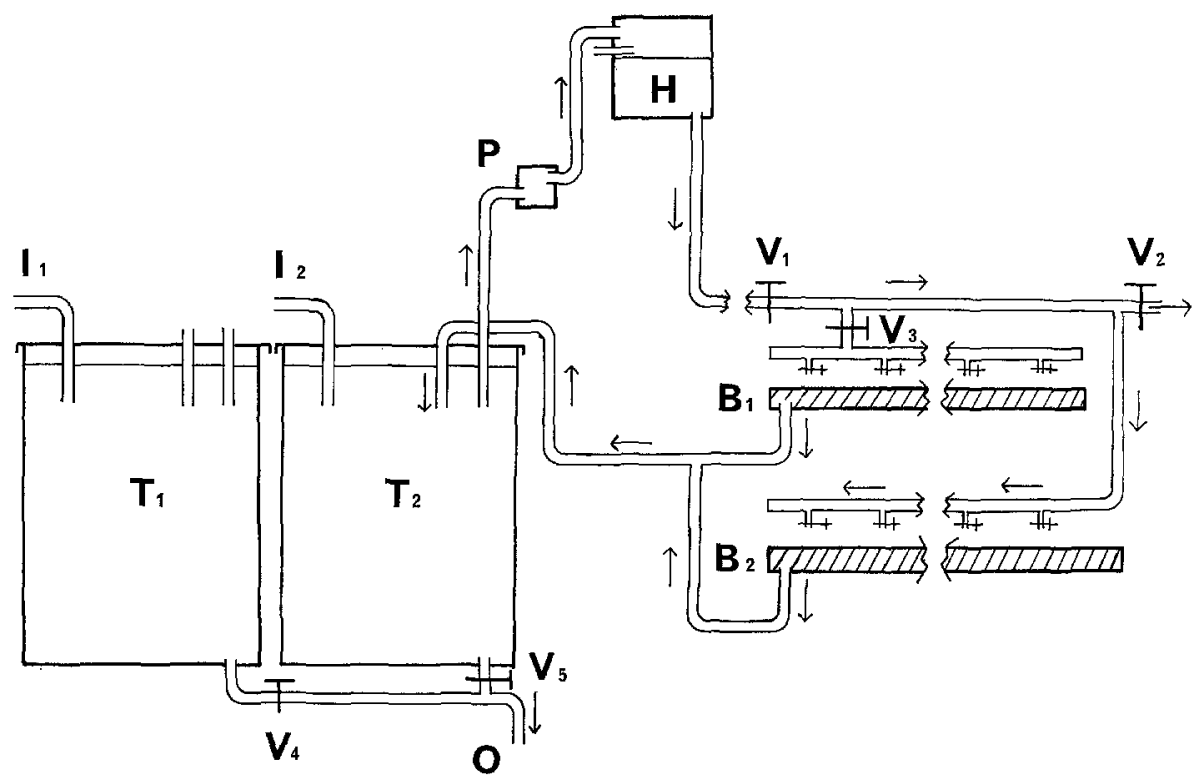

Fig. 1: Re-circulating sea water system. $T_{1}, T_{2}$, storage tanks, $P$, pump, $\mathrm{H}$, header tank. $B_{1}, B_{2}$, experimental benches. $V_{1}, V_{2}, V_{3}, V_{4}, V_{5}$, valves. $I_{1}, I_{2}$, inlet pipes to storage tanks. $O$, outlet pipe from storage tanks to drain

are $10.6 \mathrm{~m}^{2}$ of bench space in all. Any further benches will be of timber and polypropylene owing to their cheapness, ease of maintenance and cleaning. The algae under investigation are generally kept in plastic trays, $5-10 \mathrm{~cm}$ deep.

The sea water used in the laboratory is taken from the Menai Straits. It is usually possible to allow some of the grosser contaminating material to settle out in the main laboratory sedimentation tanks before pumping it to tanks $T_{1}$ and $T_{2}$, via the inlet pipes $I_{1}$ and $I_{2}$ (Fig. 1). The tanks are used alternately to supply water to the laboratory. Whilst one tank is in use the other is emptied, cleaned and refilled. A week is allowed to elapse before the water is brought into use. This allows the larger particles of suspended matter present in the water to settle out and, as the water is kept in darkness during this period, there is presumably little growth of phytoplankton present in the water. Many motile algal spores also presumably settle during this time. When the change-over is made, the supply and outlet pipes to and from the laboratory are disconnected from the tank in use and connected to the tank containing unused sea water. The used sea water is drained from the storage tanks by means of pipe $O$, the flow being controlled by valves $V_{4}$ or $V_{5}$ (Fig. 1). 


\section{OPERATIONAL PROCEDURES AND RESULTS}

The results of experimental work carried out, using this system, will be described elsewhere. It is proposed to discuss here the problems encountered while using the system and the means by which they were overcome. Observations made concerning the effect of light on the degree and type of contamination of algal cultures will also be discussed.

\section{Temperature control}

During the time that the system has been in use there has been no means of controlling water temperature, although it is hoped to install a unit for this purpose in the future.

As the storage tanks are located outside the laboratory building, the temperature of the sea water contained in them was dependent on the prevailing air temperature

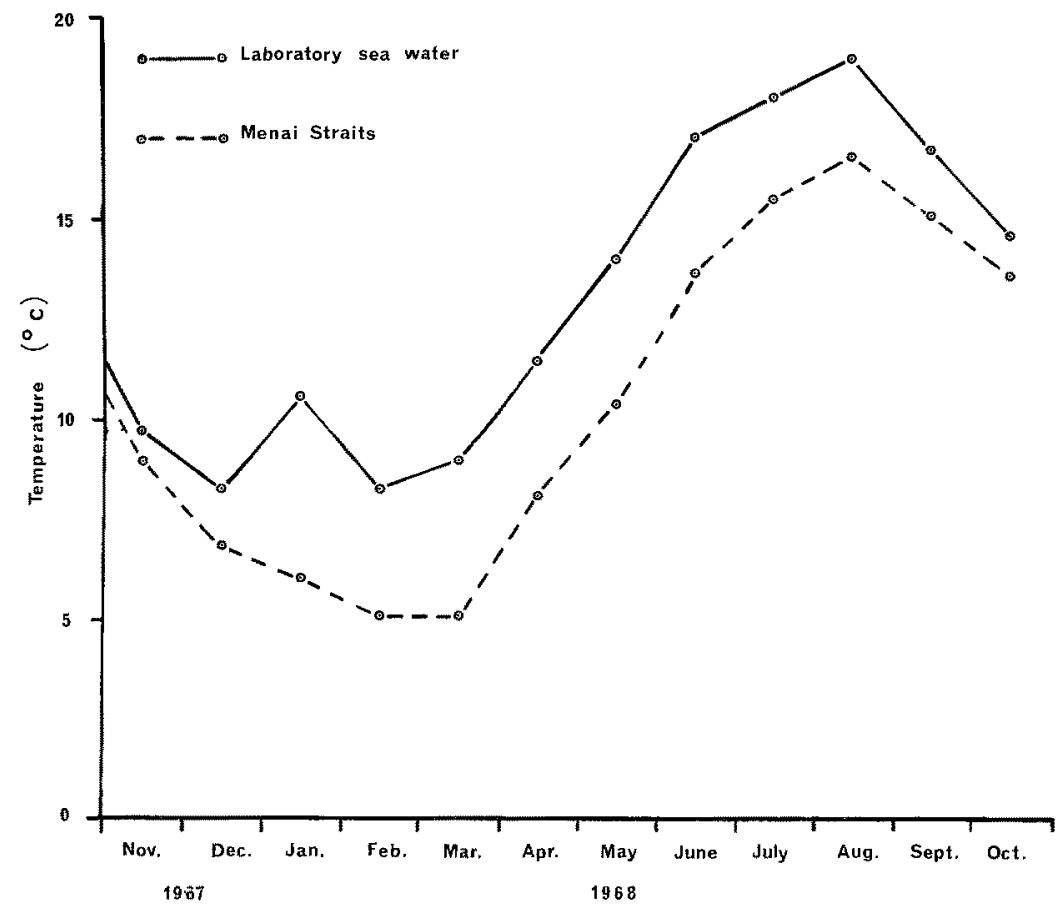

Fig. 2: Average monthly temperature of the laboratory sea water, and of the surface water of the Menai Straits from November, 1967 to October, 1968

and on the amount of sunlight falling on the storage tanks, the pump, the header tank and on the piping leading into and out of the laboratory. The rapid absorption of heat by the pipes was probably the main cause of rise in temperature. Lagging the pipes with expanded polystyrene has been partially effective. 
Figure 2 shows the average monthly temperature of the sea water in the laboratory, and the average monthly surface temperature of the Menai Straits from November, 1967 to October, 1968.

Temperature rise and fall follow a similar pattern in both cases. The water temperature rises from March until August, the difference in temperature between the two water masses remaining approximately the same during this period. The temperature then decreases, the difference in temperature between the laboratory sea water and that of the Straits being least during autumn. This is most probably due to the fact that the larger water mass of the Straits is slower in cooling, and less sensitive to air temperature, than is the comparatively small volume of water used in the laboratory. Maximal differences in temperature occur during winter and early spring; again this may be due to the fact that a small rise in air temperature would raise the temperature of the water in the storage tanks more than that of the Menai Straits. In addition, the laboratory building is heated during the winter months, and it is probable that some heating of the water occurred as it passed through the laboratory. The high average temperature recorded in January, 1968 may be explained by the fact that, as compared to December, February and March, the January air temperatures were high.

As already stated, the values shown are average values, and it should be mentioned that the fluctuations in water temperature for any one month (except in 3 cases) was greater than for that of the Menai Straits.

In summer 1968, the highest recorded temperature in the laboratory system was $19.6^{\circ} \mathrm{C}$. However, temperatures in excess of $20^{\circ} \mathrm{C}$ have been recorded, and this could conceivably have an effect on algal growth. It was thought it might be possible to counteract this by keeping the laboratory air temperature as low as possible, and a Westinghouse air conditioner was employed for this purpose. It was found to be ineffective, even when set to maintain the laboratory air temperature at $10^{\circ} \mathrm{C}$. Water flow through the system was too rapid to be affected by laboratory air temperature, at least in the summer when outside air temperatures may reach $20^{\circ}-25^{\circ} \mathrm{C}$. In the winter, however, the effect was reversed and, as already mentioned, the comparatively high temperature of the laboratory probably raises the water temperature.

\section{The presence of sediment in the water}

All the sediment present in the water is not removed, neither in the main laboratory sedimentation tanks nor during the time the water is standing in the storage tanks. Any sediment added to the water during its passage through the laboratory has little chance to settle out, owing to the rapid rate of circulation of sea water through the system.

In the case of experiments where it was required that as much suspended matter as possible be removed from the water, simple filters were inserted between the taps and the culture dishes. Each was constructed from a length of black vulcathene pipe $23 \mathrm{~cm}$ long, and $3.5 \mathrm{~cm}$ in diameter, loosely packed with glass wool. The ends were closed with rubber stoppers, through which passed the inlet and outlet tubes. 
Most of the remaining sediment, and some of the larger organisms, were removed by the filters. Many diatoms, small flagellates, and algal spores were able to pass through. As the filters were constructed of black material, multiplication of any algae trapped in them was prevented. Filters were cleaned and the glass wool replaced, at least once each week. If left for longer periods of time the filters became partially blocked, so reducing water flow.

\section{Organisms present in the water}

The principal disadvantage in using sea water which is only partially filtered for the culture of algae, is the contamination of cultures arising from the presence of organisms in the water. Algal sporelings were grown on glass slides, on which most contaminants settled easily. Of these, the most troublesome were phytoplankton organisms and the reproductive bodies of algae not in culture. Zooplankton and other small animals, if they passed through the filters, were easily removed with a camel hair brush. Many diatoms settled on the slides and on the surface of the culture dishes. In some cases it was possible to remove them with a camel hair brush, or with a jet of water, or by drawing a piece of lens tissue across the slide. However, some species were more difficult to remove without damage to the sporelings; for example, species of Nitzschia and Cocconeis.

Reproductive bodies of both micro- and macro-algae were present in the water and were very difficult to remove once established on the slides. The most prevalent species were Prasinocladus marinus (CIENK.) WAERN, Pringsheimiella scutata (REINKE) MARCHEW., Enteromorpha spp. frequently Enteromorpha prolifera (O. F. MüLL.) J. Ag. and filamentous and encrusting species of the Phaeophyceae. These were difficult to identify in the early stages of growth. Species of Cyanophyceae were also frequently present as contaminants; for example Phormidium and Calotbrix spp. but not Spirulina subsalsa (OERst.) Gom. which was a common contaminant of cultures in the previous sea water system.

The laboratory was used for the storage of algae brought in from the field, and if these were fruiting they appeared as contaminants on culture slides. It was also found that the laboratory could provide ideal conditions for the growth of algae not usually found on the Anglesey coast.

Stictyosipbon griffithsianus (LE JoL.) Holm. et BATT., brought from Pembrokeshire in summer 1967, became a major contaminant of algal cultures. In the winter it disappeared completely, probably due to the drop in temperature.

Marine fungi were seldom seen. Bacteria were present, but did not appear to be detrimental to algal growth unless present in large numbers.

The number and species of contaminants present depended on the season, the water temperature and the light intensity at which the cultures were grown. In winter, when temperatures were low there was less contamination of cultures. As experimental work was concerned with the effect of light on algal growth, the effect of light intensity on culture contamination was of particular interest. It was found that light intensity controlled both the rate of multiplication and the species present on 
culture slides. The range of intensities used in experiments ranged from 0-10,000 lux. The light was provided by Atlas "daylight" tubes. Diatoms are present at all intensities, the number of diatoms decreasing with decreasing light intensity. Pringsheimiella scutata (REINKe) Marchew. would settle but did not grow well below 1,000 lux. Prasinocladus marinus (CIENK.) WAERN although it settled and grew at intensities as low as 100 lux, did not produce large colonies at intensities below 2,500 lux. This also applies to those members of the Phaeophyceae found as contaminants. At low light intensities, that is at 1,000 lux and intensities below this, species of Cyanophyceae become the main contaminants, whereas they are few in number at higher intensities. They are fairly easy to remove, and it was found that cultures could be kept relatively free from contamination at low light intensities.

\section{DISCUSSION}

The principles involved in the operation of laboratory sea water systems have been fully described by ATz (1964). The emphasis was on keeping animal populations alive and healthy and major problems included changes due to the presence of metabolic waste products and the need for aeration. In contrast to this, we have been more concerned in our algal cultures with changes in water temperature, and with contamination resulting from organisms passing through the filtration system. However, animals (particularly Aplysia punctata CuvIER) have been kept healthy successfully for several weeks in the laboratory here, but are usually excluded to prevent a build up of animal waste products.

We had anticipated that changes in the composition of the water, and increasing numbers of bacteria might have an adverse effect on algal growth. However, there were occasions when it was not possible to change the water in the storage tanks for periods of three to six weeks. This led to an increase in water temperature, especially in the summer months, and to an increase in the number of contaminating species in the system, particularly of diatoms and bacteria; but it was found that most of the algae being cultured could withstand such conditions and that, where growth was adversely affected, the plants were able to recover when new sea water was intro-

duced into the system. A few of the more delicate species were not so resistant, and could not survive unless the water was regularly renewed. This would be an important consideration when setting up a laboratory of this kind at some distance from the sea.

The system has been in continuous use for $2^{1 / 2}$ years and no major cleaning has been required, nor have any pipes become blocked. This contrasts markedly with the main laboratory system in which, as has already been mentioned, there has been a history of interrupted flow caused by fouling organisms and sediment accumulation.

Although no means of controlling water temperature have been available, most of the experiments carried out have been of short duration, seldom more than 3-4 weeks. During these short periods, the temperature could be relied upon to remain sufficiently constant for experimental purposes. Even on those occasions when the water temperature was unusually high, there were no obvious adverse effects on 
the algae in culture. There was, however, an increase in the number of contaminating species of algae present. To reduce the numbers of contaminants passing into culture dishes a more effective filtration system would have to be installed.

Where the culture dishes were strongly illuminated, there was an additional local temperature rise, unless the water flow was rapid. It was possible to overcome this by using maximum water flow, except where the highest intensities of illumination were employed. In this case a slight temperature rise $\left(0.5^{\circ} \mathrm{C}-1.0^{\circ} \mathrm{C}\right)$ was unavoidable.

It has been found that algae can be kept in a healthy condition for long periods (over two years in some cases) so that, besides its usefulness for carrying out experiments under controlled conditions, the system has been used in studies of algal life histories (MArTin 1969). All the difficulties encountered using this system can be overcome by a suitable method of temperature control (shortly to be installed), and an effective filtration system. It would seem, from the results obtained since the system was installed, that even existing difficulties are outweighed by the advantage of being able to grow algae in an environment as nearly approaching field conditions as possible.

\section{SUMMARY}

1. A description is given of a re-circulating sea water system used to supply water for the culture of algae. Sea water is stored in two large storage tanks. From these, water is pumped to a header tank and then flows by gravity to experimental benches in the laboratory. After use, water is returned to the storage tanks. Nontoxic materials are used throughout the system.

2. It is not possible to control the temperature of the laboratory sea water. Although the temperature fluctuation of the laboratory sea water and the surface water of the Menai Straits follow a similar pattern throughout the year, the temperature of the laboratory sea water was always higher than that of the Menai Straits for the year 1967-1968. The difference between the two water masses is least $\left(0.6^{0}-1.8^{\circ} \mathrm{C}\right)$ from September-December and greatest $\left(3.0^{0}-4.6^{\circ} \mathrm{C}\right)$ from January to March. From April to August the difference varies from $2.4^{0}-3.6^{\circ} \mathrm{C}$.

3. Suspended matter is removed from the sea water by allowing sedimentation to occur in the storage tanks and by means of simple filters.

4. The principal disadvantage of using this type of system is the inevitable contamination of cultures by organisms present in the water. The number and species of contaminants depended on the season and the amount of illumination they received. Prasinocladus marinus (Ctenk.) WaERn., Pringsheimiella scutata (ReInke) MARCHEw., Enteromorpha spp., various diatoms and filamentous and encrusting Phaeophyceae were the main contaminants above 1,075 lux. At intensities below this, species of Cyanophyceae were the main contaminants.

5. The sea water system described has been found satisfactory for the culture of algae for experiments of short duration, and for keeping algae in a healthy condition for long periods. 


\section{LITERATURE CITED}

ATZ, J. W., 1964. Some principles and practices of water management for marine aquariums. In: Sea-water systems for experimental aquariums. A collection of papers. Ed. by J. R. Clark \& R. L. Clark. Res. Rep. U.S. Fish Wildl. Serv. 63, 3-16.

Jones, W. E., 1957. The autecology of Gracilaria verrucosa (Hudson) PApenfuss. Ph. D. Thesis, University of Wales.

- 1959. Experiments on some effects of certain environmental factors on Gracilaria verrucosa (Hudson) Papenfuss. J. mar. Biol. Ass. U.K. 38, 153-167.

Martin, M. T., 1969. A review of life-histories in the Nemalionales and some allied genera. Br. phycol. J. 4, 145-158.

Neushul, K., 1963. Studies on the giant kelp Macrocystis. II. Reproduction. Am. J. Bot. 50, 354-359.

- \& DaHL, A. L., 1967. Composition and growth of subtidal Parvosilvosa from Californian kelp forests. Helgoländer wiss. Meeresunters. 15, 480-488.

- Haxo, F. T., 1963. Studies on the giant kelp Macrocystis. I. Growth of young plants. Am. J. Bot. 50, 349-353.

- Scott, J., Dahl, A. L., \& Olsen, D., 1967. Growth and development of Sciadopbycus stellatus Dawson. Bull. Sth. Calif. Acad. Sci. 66, 195-200.

First author's address: Dr. W. E. Jones

University College of North Wales

Marine Science Laboratories

Menai Bridge, Anglesey, U.K. 